\title{
Update on oral health in elite sports
}

\section{DIGESTIVE SYSTEM / EDUCATION / ELITE SPORTS / SPORTS NUTRITION / TEAM MANAGEMENT}

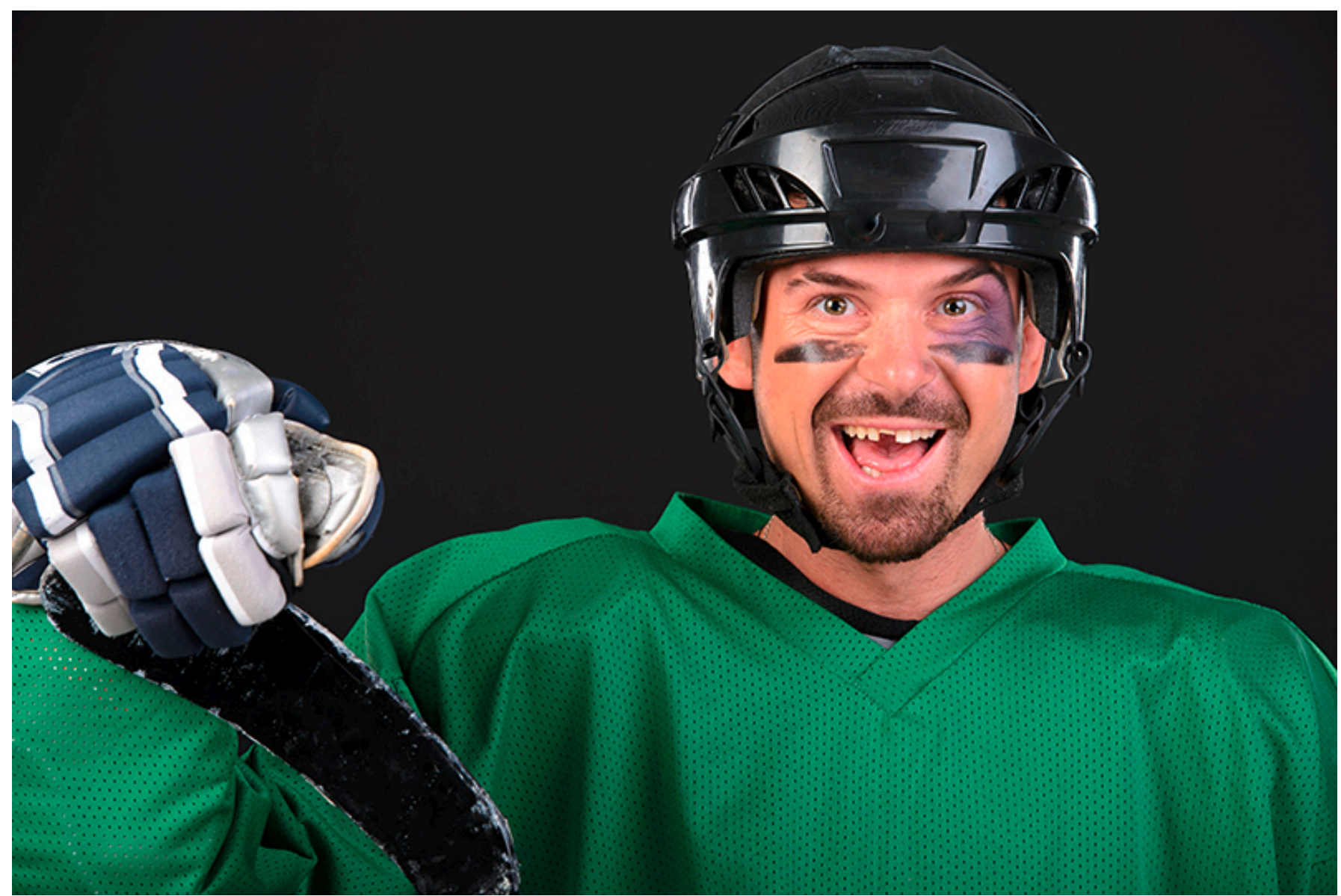

Raemy Anton, Merea Balestra Laura, Broome Martin

Division de Chirurgie Orale et Maxillo-Faciale et Centre de Médecine Dentaire, Centre Hospitalier Universitaire Vaudois, 1011 Lausanne

\section{Abstract}

Since the first report from the 1968 Olympic Games, many studies have consistently reported poor oral health in elite athletes without any differences regarding socio-economic status or continental location. Poor oral health is an important issue as it has a clear impact on quality of life, confidence, appearance and socialisation. It also has an impact on sport performance and training with impaired preparation for competition. Many causes to impaired oral health can include nutritional diet and carbohydrate supplementation, oral dehydration, depression of various aspect of the immune function due to intense exercise, negative health behaviours, lack of awareness, time and prioritisation. Facial traumas and oro- 
dental injuries have to be considered because of their high prevalence among athletes. These findings were confirmed during the Lausanne 2020 Youth Olympic Games. This update tries to raise awareness of the issues of oral health amongst health-care providers and give simple interventions and strategies for prevention and promotion.

\section{Résumé}

Depuis le premier rapport aux Jeux Olympiques de 1968, de nombreuses études ont régulièrement observé une santé buccale déficiente chez les athlètes de haut niveau, sans que des différences régionales ou de niveau socio-économique soient en cause. La mauvaise santé buccale représente un problème important avec un impact clair sur la qualité de vie, la confiance, l'apparence et la socialisation. Elle a aussi un impact sur la performance sportive et l'entrainement, sous forme de perturbation de la préparation ou de la compétition. Les nombreuses causes d'atteinte de la santé buccales comprennent le régime alimentaire et la complémentation en hydrates de carbone, la déshydratation orale, la dépression de divers aspects immuns en lien avec l'exercice intense, les comportements néfastes à la santé en général, le manque de conscience du problème ou de temps et priorisation. Les traumas faciaux et les blessures bucco-dentaires doivent aussi être considérées en raison de leur prévalence élevée dans le sport. Ces constatations ont également été observées durant les Jeux Olympiques 2020 de la jeunesse à Lausanne. Cette mise à jour tente de mettre en lumière les problèmes de santé buccale pour les professionnels de la santé, et donne quelques pistes d’interventions et des stratégies de prévention et de promotion simples.

\section{Introduction: what about oral health in elite sports?}

In contrast with the common perception that athletes have an overall excellent health, it is striking to find that the oral health of athletes is poor. Since the first report from the 1968 Olympic Games [1], many studies have consistently reported poor oral health in elite athletes, with only slight improvement, despite the trend over successive games of increasingly using dental services [2]. Dental consultations at the London Olympic Games in 2012 comprised of 30\% of all medical visits and were second only to musculoskeletal reasons for attendance [3]. One important study at the Olympic games of London 2012 [4] showed that nearly half of the athletes reported not attending a check-up or hygiene visit within the 12 months of the Games and 8.7\% reported never receiving such care. This indicates that dental care and oral health has an image of minor importance among elite athletes, and that they did not prioritize oral health in the preparation for their performance and competitions. A Dutch study of elite athletes prior to Rio 2016 showed a need for dental treatment in almost half of the sample [5]. Furthermore, the incidence of disease did not seem to be related to socio-economic status or to continental location, as poor oral health appears to affect athletes from both developing and developed countries. In conclusion, poor oral health is common in professional athletes and is similar to non-athletes of disadvantaged populations.

\section{Oral disease}

Overall, dental caries, dental erosion, periodontal disease and pericoronitis/impacted third molar are the main causes of poor oral health. During the Youth Olympic Games in Lausanne (YOG), the overall incidence was however lower for all the oral diseases, but there are very few data available comparing 
young athletes.

\section{Dental caries}

In a cross-sectional study at the dental clinic during the London Olympic Games in 2012, more than half of the athletes (55.1\%) presented with caries [4]. Other authors have reported incidences up to 75\% [6]. 41\% of the lesions were into dentine, which is irreversible and requires treatment. An average of two teeth were affected for each athlete. Another study on oral health in England reported caries in $49 \%$ of the athletes compared to $36 \%$ of adults of the general population aged 25-34 [7]. The same study showed that the odds of having caries were 2.4 times greater in team sport than endurance sport. It also appears that athletes performing more than 20h of sports a week tend to have a higher DMFT-score (diseased missing and filled teeth index) that athletes doing less than 20h sports a week [5].

\section{Dental erosion}

Dental erosion was present in $44.6 \%$ of the athletes and similar distribution in anterior and posterior regions was seen.

\section{Periodontal health}

Gingivitis, which is a reversible inflammation of the gingiva, with a score of BPE 1-2 (basic periodontal examination) was present in more than three quarters of the athletes and irreversible periodontitis in more than $15 \%$. [4]

\section{Pericoronitis and mucosae health}

Pericoronitis, which corresponds to an infection around incompletely erupted wisdom teeth, was detected in $10 \%$ of the athletes. Half of them reported symptoms of pain, and signs of unhealthy mucosae was found in $11 \%$. One in five athletes reported previous wisdom teeth problems [4].

\section{Other oral health problems}

Temporomandibular joint dysfunction (TMD) seems to have low prevalence overall, according to the dental service in the summer Olympic 2008, with only $0.15 \%$ of all the visits to the Olympic dental [8]. Even though, as studied in footballers of the F.C. Barcelona [9], bruxism was diagnosed in $30 \%$ of 30 players, clicking detected in 16.7\%, uncorrected deviation during vertical jaw opening and pain during palpation of the TMJ in 6.7\%. 60\% had class I (Angle) occlusion, while $20 \%$ had class III occlusion, and the same percentage Class II occlusion. Severe malocclusion was present in 9 players (30\%).

\section{Trauma}

Facial injuries are an unfortunate reality in sport. Unlike lacerations or fractures, dental trauma will not 
heal and often require an artificial or prosthetic replacement on a permanent basis, including high costs. Incidence reported by various studies have shown that dental and orofacial injuries are very common in sport, concerning about half of the athletes [10]. Dental trauma, as it is the most common injury, varies from 14 to 57\% [6], with 80\% involving the 4 maxillary incisor teeth. Other trauma includes maxillary/mandibular fracture, tooth avulsion, oral and facial lacerations as well as contusion. Not surprisingly, contact sports are those in which participants establish direct physical contact with other players or objects, resulting in greater likelihood of trauma and injuries. Those sports are for example football, volleyball, basketball, handball, hockey, rugby, martial arts, and others. During the Olympic games of London 2012, all sports included, $30 \%$ of athletes reported a history of previous orofacial trauma. New trauma during the games was about $17 \%$.

\section{Impact of oral health on performance}

Oral health is a crucial element of general health, well-being and a determinant of quality of life [11]. It is proved that poor oral health can affect quality of life and induce a systemic inflammatory response [12] and thus could affect athletic performance. More specifically, literature demonstrating impact of oral diseases on the QoL including caries [13], periodontal disease [14] and pericoronitis [15] is abundant. During the Olympic Games in London 2012, more than 40\% of athletes presenting to the clinic were bothered by their oral health with $28 \%$ reporting an impact on their QoL and $18 \%$ reporting an impact on training or performance [4].

\section{Why might oral health impact on performance}

There are many factors influencing the QoL regarding oral health. The most commonly reported impacts in a study about 352 British athletes from eleven different sports were difficulties with eating (34.9\%), oral pain (29.9\%), difficulty smiling (17.2\%), difficulty relaxing (15.1\%) and difficulty participation in normal training and competition (9.0\%). Performance (5.8\%) and reduction in training volume (3.8\%) was also affected. Overall, 32.0\% athletes reported an oral health-related impact on sport performance [7]. Strong statistically evidences were found for caries associated with self-reported impacts (on QoL, performance and training) through pain whether analysed by median number of carious lesions per athletes or number of athletes with caries as a direct cause. Interestingly, as the "aggregation of marginal gains" is critical in sport nowadays, the subtle effects of the impact on training and performance could turn out to be highly important. In an acute phase, severe events such as dental or orofacial infections can lead to time lost for training and even competition.

Long term concerns have not been studied in a sample of athletes, but the effect of poor oral health on these in later life is likely to cause considerable impacts, including a high treatment need with a loss of time and high costs, tooth loss, reduced oral function and psychological effect [16].

Indirect effects are relevant for further studies as oral health have clear psychological impact; it could compromise confidence and socialisation of the athletes and trapped them in a vicious circle, especially as it may be less evident conditions to athletes themselves. Interestingly, one study about Brazilian basketball players reported increased insecurity about playing after match-related orofacial trauma in 33\% [17]. 


\section{Why might athletes have poor oral health}

Athletes represent a particular class of the population with proper lifestyle and schedule. High expectancy on their physical and mental strength is solicited, which therefore gather many challenges that we will distinguish between proximal factors close to the athletes and distal or more downstream factors.

\section{Proximal factor}

Nutritional intake is one of the most important aspect of the oral health, including usual diet which is often carbohydrate intake and sports drinks with their low $\mathrm{pH}$ and high concentrations of fermentable carbohydrate. Dietary carbohydrate intake is one of the most well-characterised causative factors for dental caries [18] and acidic food or beverages are the main factors causing erosion [19,20]. They however play an important role in lifestyle, performance and recovery for competitive athletes [21). Indeed, training and performance are often supported by carbohydrate-containing sports drinks and gels [22], which are frequently taken during activity in a high risk consumption pattern of "little sips often from a bottle” [23]. Regarding periodontal disease, carbohydrate intake with its proinflammatory effects might also increase that risk [24].

Another aspect of the nutrition is the body weight, composition and aesthetics which are crucial factors for the athletes [25], therefore increasing the risk of eating disorders (ED). Eating disorders, such as anorexia nervosa and bulimia nervosa, is higher in athletes (13.5\%) than in controls (4.6\%), higher in female athletes (20\%) than in male athletes (8\%), and more common among those competing in leannessdependent and weight-dependent sports than in other sports, illustrating the relative importance of this problem in the athletic community [26]. Consequently, early detection of ED could prevent further detrimental effects both physically and mentally [27] and this is why dentists should detect signs and symptoms of tooth erosion as a result of eating disorders [28]. Screening of the athletes becomes not only critical for dental disease but also for the earliest signs of mental disorders that manifest themselves in the oral cavity.

Mucosal secretions like saliva play an important role in immunity as the first line of defence against potential pathogens invading the oral cavity and upper respiratory tract [29]. Depression of various aspect of the immune function like lowering of the antimicrobial activity of the saliva has been studied and proved during and following prolonged exercise, acutely and chronically [30,31], plus exercising in a state of hypohydration has the potential for a disturbed immune response [32]. Mouth breathing dries the oral cavity and reduces the salivary flow [33]. Dehydration and exercise-induced immune suppression have thus an impairment on the protective proprieties of the saliva. Decreased first line immunity of the oral cavity and upper respiratory tract could increase the impact of the carbohydrate on caries. Higher risk for dental erosions, exercise-dependent caries risk, and load-dependent changes in saliva parameters point out the need for risk-adapted preventive dental concepts in the field of sports dentistry [34]. Apart of the oral health which is heavily affected, the main cause of impairment because of illness is infections of the respiratory system, mostly upper respiratory tract infections [35].

Concerning dentoalveolar injuries such as tooth avulsion, fracture, subluxation, and intrusion which have a high incidence in contact sports, prevalence of wearing a mouthguard has been significantly higher in recent studies growing from $31.4 \%$ in the 1980 's and 1990's, to $84.5 \%$ nowadays, with an overall proportion of $57.9 \%$ despite a high heterogenicity [36]. In a recent systematic-review of mouthguards effectiveness in 
dental trauma, the authors concluded that mouthguards contribute to a lower prevalence of dentoalveolar trauma among athletes of contact sports [37]. However, athletes' attitude toward wearing a mouthguard and its interest is still controversial, as $55.4 \%$ of athletes evaluate wearing a mouthguard as unnecessary and complained about it. A properly fitted mouth guard must be protective, comfortable, resilient, tear resistant, odourless, tasteless, not bulky, causing minimal interference to speak and breath, have excellent retention, fit, and sufficient thickness in critical areas. There are three types of mouthguard; the stock mouthguard, available at most sporting goods stores, is the least expensive and the least protective. The mouth-formed or boil-and-bite mouthguard, most commonly used, represent with the stock mouthguard $90 \%$ of the worn mouthguards bought in sporting goods stores, and provide a false sense of protection as they readily distort and often lack proper thickness. Finally, the custom-made mouthguard, supplied by a dentist, is the most satisfactory of all types of mouth protectors and fulfil all the criteria of optimal protection [10]. Many mouthguard manufacturers have claimed that their product reduce either incidence or severity of concussion, improve neuromuscular relaxation and enhance performance; there is at the time no clear scientific evidence of these statements, but absence of proof is not proof of absence.

\section{Distal factor}

Oral health comes in a complex environment where different determinants should be considered to make a global understanding and de facto awareness of the situation. For example, health behaviours, health beliefs and oral health literacy are all well-recognised important determinants of oral health [38] and contribute to raising awareness among people. Little is known about these factors in elite sport, but the demanding training regimes of the athletes and therefore the lack of time and prioritisation for oral health within the difficulty to access preventive programmes make an important field of interest and a huge potential to improve. The access to preventive programmes could also be rather difficult, even where organised dental care is available as some of the traditional models of clinics focus on treatment a lot more than on preventing disease or promoting health [39,40,41]. Regarding the organisation for sport events such as The Olympics, it would be a misjudgement to consider an athlete as isolated. Rather, the athletes including their knowledges, behaviours and health, are very likely to be influenced or even dependent on the environment and surrounding network of peers [42].

\section{Promotion, prevention, mitigation and perspective}

"The possibility of an athlete losing four hard years of training due to an avoidable dental illness or injury is unacceptable and steps must be taken to prevent these occurrences” [1]. This quotation dates from a half century ago and is still prevalent. According to the Olympic Charter, the International Olympic Committee and the International Sport Federations have an obligation "to encourage and support measures protecting the health of athletes" [43]. However, despite the widespread knowledge of the importance of the promotion of physical activities on global health, there are gaps in programming demonstrating that International Sport Federations are missing important area of athlete health such as oral health [44]. Reduced performance due to oral health is unacceptable as well as preventable with well-characterised interventions at low cost. Some of the interventions are summarised table 1 . These recommendations included nutritional change behaviour with limited and controlled pattern of use of sports drinks and 
decreased intake of carbohydrate, behaviour change related to oral health with high strength fluoride toothpaste and use of fluoride mouth rinse, promote oral prevention and awareness with regular and monitored dental check-ups and the use of custom-made mouthguards for contact sports. Nevertheless, it is unrealistic to think that athletes can get rid of essential diet elements. Therefore, preventive approaches in regulating the risk factors such as protective products (mouth rinse) and especially raising their awareness by regular assessments of dental professional will allow mitigation of the risks and personalisation of prevention plans, early treatment and promotion of oral health. Trainers, national sport funders and policy organisation have to be included for integrating such an approach. Several of these interventions rely on behaviour which are difficult to change [45]. To achieve a steady effect, the expression of oral health in an individual athlete must be considered because of an imbrication of factors including the structural issues and the inter-relationship of athletes within their local environment, sport and peer networks. Therefore, interventions which are based upon behaviour change theory [46] and involve actors at many levels to improve a comprehensive targeting may have better chance of success [47]. This lack of knowledge and prioritisation was clearly observed during the YOG, with very few sport federation organising a dental check in the year before the games. Many trainers contacted at the Olympic village, considered the free dental check during the games as a waste of time.

\section{Further research}

Some specific fields need to be assessed, as there is a certain lack of scientific literature around orthodontic problems in athletes. This could include occlusion disorder, leading to breathing disorder due to a malposition of the tongue.

Furthermore, future research should include epidemiological studies of oral health and impact on training and performance. These data will help to point out the needs across different sports and countries, the different determinants of both oral health and impact on performance, in consideration of athletes and their environment. Obviously, strategies of risk mitigation, promotion and changing health behaviour need to be developed and tested. Such a research calls for expertise across oral health, sports and exercise medicine, public engagement, sports governing and funding organisations.

\section{Conclusion/practical implications}

Poor oral health is common in professional athletes. Prevention and education of these problems must be more implemented to help them with their performances.

\section{Acknowledgments, conflict of interest and funding}

None declared.

\section{Corresponding author}




\section{Martin Broome}

Av. Bugnon 46

1011 Lausanne - CHUV

+41213144199

Martin.Broome@chuv.ch

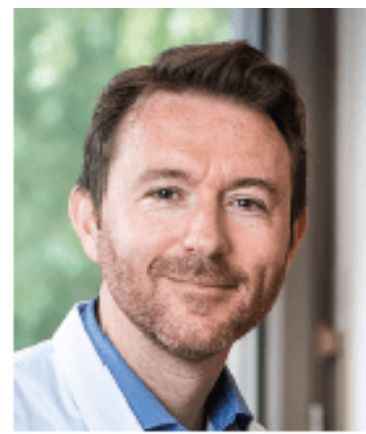

\begin{tabular}{|c|c|}
\hline Context & Measures \\
\hline Overall & $\begin{array}{l}\text { Health behaviour, health promotion, awareness: Multilevel approach as individual (athlete), } \\
\text { surrounding environment (coach, trainers, physician and dentist] and high level (national/ } \\
\text { international sport federation) } \\
\text { Dental check-ups: more frequently lat least } 2 x / \text { year) especially pre-season, personalised advise } \\
\text { (mouthguard, oral hygiene) }\end{array}$ \\
\hline Dental caries & $\begin{array}{l}\text { Diet: decrease intake of supplements containing carbohydrate. Work with sports nutrition to try } \\
\text { alternatives } \\
\text { Fluoride: fluoridated toothpaste containing at least } 1400 \mathrm{ppm} \\
\text { Oral hygiene: brushing teeth twice a day and last thing at night, spit out after brushing but do } \\
\text { not rinse, use fluoride mouth-rinse daily, interdental cleaning }\end{array}$ \\
\hline Periodontal disease & $\begin{array}{l}\text { Oral hygiene: daily dental plaque removal [toothbrushing and interdental cleaning] } \\
\text { Assessment: frequent check-ups for early detection and treatment } \\
\text { Risk factor: smoking cessation }\end{array}$ \\
\hline Dental erosion & $\begin{array}{l}\text { Diet: acidic food/beverage intake as limited as possible } \\
\text { Sport drinks: reduced frequency, no retention in mouth and try to rinse with water after, try to } \\
\text { avoid pattern "little sips often from a bottle" }\end{array}$ \\
\hline Pericoronitis & $\begin{array}{l}\text { Oral hygiene: plaque removal around impacted third molar, extraction of the wisdom teeth after } \\
>2 \text { episodes of pericoronitis }\end{array}$ \\
\hline Trauma & $\begin{array}{l}\text { Dental check-up: promotion/awareness of mouthguards, custom-made mouthguard by dentists } \\
\text { when possible }\end{array}$ \\
\hline
\end{tabular}

\section{References}

1. Forrest JO. The dental condition of Olympic Games contestants-a pilot study, 1968. Dent Pract Dent Rec. nov 1969;20(3):950101.

2. Piccininni PM, Fasel R. Sports dentistry and the olympic games. J Calif Dent Assoc. juin 2005;33(6):471ธ83.

3. Vanhegan IS, Palmer-Green D, Soligard T, Steffen K, O’Connor P, Bethapudi S, et al. The London 2012 Summer Olympic Games: an analysis of usage of the Olympic Village «Polyclinic» by competing athletes. Br J Sports Med. mai 2013;47(7):415ロ9.

4. Needleman I, Ashley P, Petrie A, Fortune F, Turner W, Jones J, et al. Oral health and impact on performance of athletes participating in the London 2012 Olympic Games: a cross-sectional study. $\mathrm{Br}$ J Sports Med. nov 2013;47(16):1054ロ8.

5. Kragt L, Moen MH, Van Den Hoogenband C-R, Wolvius EB. Oral health among Dutch elite athletes 
prior to Rio 2016. Phys Sportsmed. 2019;47(2):182ロ8.

6. Ashley P, Di Iorio A, Cole E, Tanday A, Needleman I. Oral health of elite athletes and association with performance: a systematic review. Br J Sports Med. janv 2015;49(1):14ロ9.

7. Gallagher J, Ashley P, Petrie A, Needleman I. Oral health and performance impacts in elite and professional athletes. Community Dent Oral Epidemiol. 2018;46(6):563ロ8.

8. Yang X-J, Schamach P, Dai J-P, Zhen X-Z, Yi B, Liu H, et al. Dental service in 2008 Summer Olympic Games. Br J Sports Med. avr 2011;45(4):270ロ4.

9. Gay-Escoda C, Vieira-Duarte-Pereira D-M, Ardèvol J, Pruna R, Fernandez J, Valmaseda-Castellón E. Study of the effect of oral health on physical condition of professional soccer players of the Football Club Barcelona. Med Oral Patol Oral Cirugia Bucal. 1 mai 2011;16(3):e436-439.

10. Piccininni P, Clough A, Padilla R, Piccininni G. Dental and Orofacial Injuries. Clin Sports Med. avr 2017;36(2):369ロ405.

11. Locker D. Measuring oral health: a conceptual framework. Community Dent Health. mars 1988;5(1):3ロ18.

12. Cullinan MP, Seymour GJ. Periodontal disease and systemic illness: will the evidence ever be enough? Periodontol 2000. juin 2013;62(1):271ロ86.

13. Foster Page LA, Thomson WM. Caries prevalence, severity, and 3-year increment, and their impact upon New Zealand adolescents' oral-health-related quality of life. J Public Health Dent. 2012;72(4):287ロ94.

14. Needleman I, McGrath C, Floyd P, Biddle A. Impact of oral health on the life quality of periodontal patients. J Clin Periodontol. juin 2004;31(6):45407.

15. McNutt M, Partrick M, Shugars DA, Phillips C, White RP. Impact of symptomatic pericoronitis on health-related quality of life. J Oral Maxillofac Surg Off J Am Assoc Oral Maxillofac Surg. déc 2008;66(12):2482प7.

16. Locker D, Quiñonez C. To what extent do oral disorders compromise the quality of life? Community Dent Oral Epidemiol. févr 2011;39(1):3111.

17. Frontera RR, Zanin L, Ambrosano GMB, Flório FM. Orofacial trauma in Brazilian basketball players and level of information concerning trauma and mouthguards. Dent Traumatol Off Publ Int Assoc Dent Traumatol. juin 2011;27(3):208ロ16.

18. Moynihan PJ, Kelly S a. M. Effect on caries of restricting sugars intake: systematic review to inform WHO guidelines. J Dent Res. janv 2014;93(1):8118.

19. Noble WH, Donovan TE, Geissberger M. Sports drinks and dental erosion. J Calif Dent Assoc. avr 2011;39(4):233ロ8.

20. Lussi A, Jaeggi T, Zero D. The role of diet in the aetiology of dental erosion. Caries Res. 2004;38 Suppl $1: 34 \square 44$.

21. Gallagher J, Ashley P, Petrie A, Needleman I. Oral health-related behaviours reported by elite and professional athletes. Br Dent J. août 2019;227(4):276ロ80.

22. Lun V, Erdman KA, Fung TS, Reimer RA. Dietary supplementation practices in Canadian highperformance athletes. Int J Sport Nutr Exerc Metab. févr 2012;22(1):3107.

23. Bryant S, McLaughlin K, Morgaine K, Drummond B. Elite athletes and oral health. Int J Sports Med. sept 2011;32(9):720ロ4.

24. Chapple ILC. Potential mechanisms underpinning the nutritional modulation of periodontal inflammation. J Am Dent Assoc 1939. févr 2009;140(2):178ロ84.

25. Sundgot-Borgen J, Garthe I. Elite athletes in aesthetic and Olympic weight-class sports and the challenge of body weight and body compositions. J Sports Sci. 2011;29 Suppl 1:S101-114.

26. Sundgot-Borgen J, Torstveit MK. Prevalence of eating disorders in elite athletes is higher than in the general population. Clin J Sport Med Off J Can Acad Sport Med. janv 2004;14(1):25口32.

27. Joy E, Kussman A, Nattiv A. 2016 update on eating disorders in athletes: A comprehensive narrative 
review with a focus on clinical assessment and management. Br J Sports Med. févr 2016;50(3):154ロ62.

28. Hermont AP, Pordeus IA, Paiva SM, Abreu MHNG, Auad SM. Eating disorder risk behavior and dental implications among adolescents. Int J Eat Disord. nov 2013;46(7):677083.

29. Gleeson M, Pyne DB. Special feature for the Olympics: effects of exercise on the immune system: exercise effects on mucosal immunity. Immunol Cell Biol. oct 2000;78(5):536ロ44.

30. Gleeson M, McDonald WA, Pyne DB, Cripps AW, Francis JL, Fricker PA, et al. Salivary IgA levels and infection risk in elite swimmers. Med Sci Sports Exerc. janv 1999;31(1):67073.

31. Walsh NP, Gleeson M, Shephard RJ, Gleeson M, Woods JA, Bishop NC, et al. Position statement. Part one: Immune function and exercise. Exerc Immunol Rev. 2011;17:6ロ63.

32. Maresh CM, Whittlesey MJ, Armstrong LE, Yamamoto LM, Judelson DA, Fish KE, et al. Effect of hydration state on testosterone and cortisol responses to training-intensity exercise in collegiate runners. Int J Sports Med. oct 2006;27(10):765070.

33. Mulic A, Tveit AB, Songe D, Sivertsen H, Skaare AB. Dental erosive wear and salivary flow rate in physically active young adults. BMC Oral Health. 23 mars 2012;12:8.

34. Frese C, Frese F, Kuhlmann S, Saure D, Reljic D, Staehle HJ, et al. Effect of endurance training on dental erosion, caries, and saliva. Scand J Med Sci Sports. juin 2015;25(3):e319-326.

35. Engebretsen L, Soligard T, Steffen K, Alonso JM, Aubry M, Budgett R, et al. Sports injuries and illnesses during the London Summer Olympic Games 2012. Br J Sports Med. mai 2013;47(7):407014.

36. Vucic S, Drost RW, Ongkosuwito EM, Wolvius EB. Dentofacial trauma and players' attitude towards mouthguard use in field hockey: a systematic review and meta-analysis. Br J Sports Med. mars 2016; 50(5):298ロ304.

37. Fernandes LM, Neto JCL, Lima TFR, Magno MB, Santiago BM, Cavalcanti YW, et al. The use of mouthguards and prevalence of dento-alveolar trauma among athletes: A systematic review and meta-analysis. Dent Traumatol Off Publ Int Assoc Dent Traumatol. févr 2019;35(1):54ロ72.

38. Watt RG. Emerging theories into the social determinants of health: implications for oral health promotion. Community Dent Oral Epidemiol. août 2002;30(4):24107.

39. Sbaraini A. What factors influence the provision of preventive care by general dental practitioners? Br Dent J. 8 juin 2012;212(11):E18.

40. Yokoyama Y, Kakudate N, Sumida F, Matsumoto Y, Gilbert GH, Gordan VV. Dentists' practice patterns regarding caries prevention: results from a dental practice-based research network. BMJ Open. 24 sept 2013;3(9):e003227.

41. Pearce M, Catleugh M. Are general dental practitioners providing best practice in prevention in everyday general practice? Prim Dent J. juill 2013;2(3):38ロ43.

42. Steffen K, Soligard T, Engebretsen L. Health protection of the Olympic athlete. Br J Sports Med. juin 2012;46(7):466口70.

43. Mountjoy M, Junge A. The role of International Sport Federations in the protection of the athlete's health and promotion of sport for health of the general population. Br J Sports Med. nov 2013;47(16):1023प7.

44. Mountjoy M, Costa A, Budgett R, Dvorak J, Engebretsen L, Miller S, et al. Health promotion through sport: international sport federations' priorities, actions and opportunities. Br J Sports Med. janv 2018; 52(1):54ロ60.

45. Matheson GO, Klügl M, Engebretsen L, Bendiksen F, Blair SN, Börjesson M, et al. Prevention and management of non-communicable disease: the IOC consensus statement, Lausanne 2013. Br J Sports Med. nov 2013;47(16):1003ロ11.

46. Michie S, van Stralen MM, West R. The behaviour change wheel: a new method for characterising and designing behaviour change interventions. Implement Sci IS. 23 avr 2011;6:42.

47. Dijkstra HP, Pollock N, Chakraverty R, Alonso JM. Managing the health of the elite athlete: a new integrated performance health management and coaching model. Br J Sports Med. avr 
2014;48(7):523ロ31.

MOUTHGUARDS ORAL HEALTH SPORT DENTISTRY 